\title{
Sublethal effect of Abamectin in the functional response of the predator Phytoseiulus persimilis (Athias-Henriot) on Tetranychus urticae (Koch) (Acari: Phytoseiidae, Tetranychidae)
}

\author{
J. I. Monjarás-Barrera ${ }^{a}$, J. C. Chacón-Hernández ${ }^{b}$ E. Cerna-Chávez ${ }^{a}$, Y. M. Ochoa-Fuentes ${ }^{a}$, \\ L. A. Aguirre-Uribe and J. Landeros-Flores ${ }^{a *}$
}

${ }^{a}$ Departamento de Parasitología, Universidad Autónoma Agraria Antonio Narro, Calzada Antonio Narro, 1923, CP 25315, Buenavista, Saltillo, Coahuila, México

'Instituto de Ecología Aplicada, Universidad Autónoma de Tamaulipas, División del Golfo, 356, Colonia Libertad, CP 87019, Cd. Victoria, Tamaulipas, México

*e-mail: jlanflo@uaaan.mx

Received: May 18, 2017 - Accepted: October 17, 2017 - Distributed: May 31, 2019

(With 1 figure)

\begin{abstract}
The biological control used for the control of Tetranychus urticae (Koch) is the predator mite Phytoseiulus persimilis (Athias-Henriot). It is important to the know the effects of acaricides on the biological behavior the Abamectin on the functional response of $P$. persimilis. The functional response of the predator was of type II exposed to concentration of Abamectin, the functional response parameters: successful attack rate (a'), handling time (Th), search efficiency and the maximum predation theory $(\mathrm{T} / \mathrm{Th})$ were affected by the acaricide. The predator spends more time in persecute, dominate, consume and prepair it self to the next searching comparing with the proof subject an the predation ability was affected.
\end{abstract}

Keywords: two-spotted spider mite, predator, Abamectin, functional response, sublethal effect.

\section{Efeito subletal da Abamectina na resposta funcional do predador Phytoseiulus persimilis (Athias-Henriot) em Tetranychus urticae (Koch) (Acari: Phytoseiidae, Tetranychidae)}

\begin{abstract}
Resumo
O controle biológico utilizado para o controle de Tetranychus urticae (Koch) é o acaro predador Phytoseiulus persimilis (Athias-Henriot). É importante conhecer os efeitos dos acaricidas sobre o comportamento biológico do predador. Foi avaliado o efeito tóxico de a Abamectina na resposta funcional de $P$. persimilis. A resposta funcional do predador foi tipo II exposta a concentrações subletais de Abacmetina, os parâmetros da resposta funcional: taxa de ataque (a'), tempo de manipulação (Th), a eficiência na procura e predação teórica máxima ( $\mathrm{T} / \mathrm{Th}$ ) foram afetados pelo acaricida. O predador passa mais tempo na procura, dominar, consumir e se preparar para a próxima procura em comparação com a testemunha e sua capacidade de predação foi afetada.
\end{abstract}

Palavras-chave: ácaro rajado, predador, Abamectina, resposta funcional, efeitos subletais.

\section{Introduction}

The two spotted spider mite is an important pest in a wide scale of free and protected cultivations in the world (Van Leeuwen et al., 2010) and one of the most important pest in greenhouse rose (Van de Vrie, 1985). Population densities between 10-15 mites per leaf cause a reduction of the floral stem of $17 \%$ and $26 \%$ respectively in relation to plants free of mites (Landeros et al., 2004). Its control is mainly based on the use of acaricides; however, becaused of its high fertility, inbreeding which, may be arrhenotokia type and results in several generations per year, is able to develop resistance and survive the applications of acaricides which increases the production costs, and reduces crop profitability (Cranham y Helle, 1985; Van Leeuwen et al., 2010). Alternatives have been sought that in conjunction with the use of pesticides and biological controls or in an independent way can be use in management of this pest (IPM). A sustainable alternative constitutes the biological control (Oliveira et al., 2009) although combine use of these two methods is possible only if the naturals enemies are adapted to resist the pesticides used, so the handling of this pest would be very useful (Ibrahim and Yee, 2000). Methods to test side effects of the pesticides have been 
developed in function of natural enemies. Studies designed to evaluate the effects of pesticides on predators often focus on detection and consumption of prey (Desneux et al., 2007). To define the predator's success on the prey, it is necessary to determine the functional response, that is, the capacity of predators to adjust the feeding rate to the changes in the densities of the prey (Solomon, 1949). The objective of this research was to study the effect to concentrations of abamectin on the capacity of predators $P$. persimilis over T. urticae in rose cultivations.

\section{Materials and Methods}

The experiment was carried out in a bioclimatic chamber of the Department of Agricultural Parasitology of the Autonomous Agrarian University Antonio Narro. It was used a Laboratory colony of T. urticae (prey) previously established under conditions controlled of $25 \pm 2{ }^{\circ} \mathrm{C}$, relative humidity of $60-70 \%$ and a photoperiod of 12 hours on plants of bean (Phaseolus vulgaris L.). The population of $P$. persimilis (predator) was obtained from a commercial way SPIDEX $\AA$, of the Mexican company Koppert. The population of the predator was kept on highly infested bean plants with T. urticae, using for this purpose breeding cylinders (Fournier et al., 1985) under the same laboratory conditions than for the breeding of the prey.

Homogeneous populations were obtained from both species placing 100 fertilized female adults in disc leaves of Royal variety of Rose of $1 \mathrm{~cm}$ in diameter, those discs were placed in plastic petri boxes of $5 \mathrm{~cm}$ in diameter to which they were placed in the back ground cotton with water to saturation. After $24 \mathrm{hr}$ the females of both species were removed leaving only the eggs, which hatched and they developed until they reached their adult state.

A test was initially conducted to determine the range of concentration-mortality. The concentration of Abamectin were prepared with distilled water beginning of the commercial product Agrimec $\AA(1.8 \% \mathrm{CE})$ and the adjuvant Bionex ${ }^{\circledR}$ to a concentration of $0.1 \%$. We used the leaf dip method (modified from Helle and Overmeer, 1985 and Castagnoli et al., 2005): twenty experimental units were carried out and each unit with 20 females of $P$. persimilis with sufficient food (different development state of T. urticae). Seven concentrations were used in a range from 0 to $50 \mathrm{ppm}$ in females of $P$. persimilis of five days of age, they were immersed for 5 seconds in each concentration. Treated discs were paced in plastic petri boxes on moistened cotton, 24 hours later mortality data were taken, and the data were analyzed statistically (Probit analysis) using the maximum verosimilitude method (Finney, 1971), previously it was applied the Abbot's corrected mortality formula (Abbott, 1925).

To develop the main experiment, 2 different concentrations of Abamectin were used (1.02 and $1.52 \mathrm{ppm}$ ) and control (distilled water). The females that survived after $24 \mathrm{hr}$ of exposure to acaricide during bioassay to determine the $\mathrm{LC}_{50}$ were used for the study of depredation. Female $P$. persimilis were placed kept fasting in discs of $5 \mathrm{~cm}$ of diameter, then submerged for 5 seconds in the different concentrations using the methodology previously described and transferred individual to discs of rose leaf to which previously they had been placed females of $T$. urticae of 2 days of ripening to densities of 1, 2, 4, 8, 16, 32 and 64. Each density was repeated for 15 times and the depredation was recorded at $24 \mathrm{hr}$ of exposure.

The functional response was determined in two stages. First, the type of functional response (curve shape) was determined by the analysis of regression logistic, adjusting a polynomial equation of the proportion of preys consumed $\left(N_{\alpha} / N_{0}\right)$ against the number of preys offered $\left(N_{o}\right)$ (Juliano, 2001).

$$
\frac{N_{a}}{N_{o}}=\frac{\operatorname{Exp}\left(P_{0}+P_{1} N_{1}+P_{2} N_{o}^{2}+P_{3} N_{o}^{3}\right)}{1+\operatorname{Exp}\left(P_{0}+P_{1} N_{1}+P_{2} N_{o}^{2}+P_{3} N_{o}^{3}\right)}
$$

$N_{a}=$ number of prey consumed

$N_{o}=$ number of prey offered

$P_{0}^{\circ}, P_{1}, P_{2}$ y $P_{3}=$ parameters to be estimated

The regressions were made by starting with the cubic model and the most order coefficients that were not significantly different from zero were eliminated, until all the coefficients that remained in the model were significantly different from zero. The symbol of the linear parameter $P_{1}$ is used to distinguish between the functional response type II and type III, if $P_{1}<0$, the proportion of preys consumed decreases monotonically with the initial number of preys offered, and in this way, describes the functional response of type II; but if $P_{l}>0$, the proportion of preys consumed is positively dependent on the initial density, in this way the functional response of type III is described (Juliano, 2001), the parameters were estimated by PROC NLIN of SAS/STAT (SAS Institute, 2008).

The parameters of the functional response were estimated (time of handling and coefficient of attack) using the model of Holling (1959) for functional response type II trough a non linear regression of the number of preys consumed against the density of preys offered:

$N_{a}=\frac{a^{\prime} N_{o} T}{1+a^{\prime} N T_{h}}$

$N_{a}=$ number of preys consumed

$a^{\prime}=$ constant attack rate

$N_{o}=$ prey density

$T=$ total time available

$T_{h}=$ handling time

Non linear regression was worked with the procedure PROC NLIN SAS/STAT (SAS Institute, 2008).

\section{Results and Discussions}

The relationship concentration-mortality of $P$. persimilis after $24 \mathrm{hr}$ of exposure to Abamectin according to the analysis probit, the $\mathrm{LC}_{50}$ was $8.35 \mathrm{ppm}$ with a confidence interval to 6.36 to $11.96(\mathrm{p} \leq 0.05)$. These results are lower than the ones reported by Nour and Abdallah (2013) which 
recorded a $\mathrm{LC}_{50}$ for the predator P. persimilis of $0.5339 \mathrm{ml} / \mathrm{L}$ after one day of exposure to Abamectin. While that Kim and Yoo (2002) report that Milbectin was highly toxic to $1 \mathrm{ml} / \mathrm{L}$ with total mortality between one and three days ofter exposure to the product and Saenz-de-Cabezón et al. (2007) records an average of $26.4 \%$ of mortality three days after the treatment to concentration of $93 \mathrm{ppm}$ to Abamectin. Nadimi et al. (2011) recorded average mortality rate of 62.20 and $73.35 \%$ after three days of exposure to 0.1 and $0.05 \mathrm{ml} / \mathrm{L}$ of Abamectin respectively.

Negative values were obtained in the linear parameter $\left(P_{1}<0\right)$ in this study conforming the functional response type II for all treatments ( $\mathrm{LC}_{10}, \mathrm{LC}_{15}$ and control) (Equation 1) (Table 1). Similar results were obtained by Seiedy et al. (2012), with the same predator and prey on cucumber leaf discs. The depredation of $P$. persimilis tended to decrease with the density of the prey, possibly owning to an increase in a satiety of the predator in the most dense areas. The feeding of the predator increased at an accelerated rate when the density of the prey was between 16 and 64 preys; while for treatments $\left(\mathrm{LC}_{10}, \mathrm{LC}_{15}\right)$ this was not observed, these were less notorious. The maximum consumption of $P$. persimilis was observed in the control (21.2 females of T. urticae), followed by $\mathrm{LC}_{10}(1.02 \mathrm{ppm})$ and $\mathrm{LC}_{15}(1.52 \mathrm{ppm})$ treatments, with 15.6 and 10.0 preys consumed respectively (Table 2 ).
It has been observed that not only the mites are affected by the application of sublethal doses or pesticides residues, other organisms commonly used for the biological control are also exposed to changes in their demographic behavior and the functional response (Stark et al., 2004; Talebi et al., 2008, Sohrabi et al., 2014). In this case, mites exposed to sublethal concentrations did not show a change in their functional response, but positive in its efficiency (Table 1; Figure 1). The exposition to insecticides, is associated with a change to the asymptote, but not in the shape of the curve of the functional response, a lower asymptote of the functional response curve is an indication in decreasing the effectiveness of predation (Martinou and Stavrinides, 2015), in this respect $P$. persimilis shew loss prey consumptions in the treatments compared to the control (Table 2). The consumptions of preys decreased by $44.99 \%$ and $39.79 \%$ in $\mathrm{LC}_{10}$ and $\mathrm{LC}_{15}$ respectively, which indicated a negative effect of Abamectin on the predator activity of $P$. persimilis. Hernández et al. (2014) they fund some effect with the predator Chrysoperla carnea, in which the curve was not affect by to effect of Abamectin, but if decreased significantly the consumption of preys.

Was observed a significant decrease in attack rate $\left(a^{\prime}\right)$ and an increased in the handling time $(T h)$ indicating a negative effect of the acaricide on the predation of $P$. persimilis (Equation 2) (Table 2). Therefore, the predator requires

Table 1. Estimated parameters for the logistic regression of the proportion of consumed preys by Phytoseiulus persimilis vs the initial number of preys offered from Tetranychus urticae ( $\mathrm{Na} / \mathrm{No})$.

\begin{tabular}{cccc}
\hline \multirow{2}{*}{ Treatments } & \multicolumn{3}{c}{ Parameters } \\
\cline { 2 - 4 } & Intercept $\left.\mathbf{( P}_{\mathbf{0}}\right)$ & Lineal $\left(\mathbf{P}_{\mathbf{1}}\right)$ & Quadratic $\left(\mathbf{P}_{\mathbf{2}}\right)$ \\
\hline Control & 2.6161 & -0.0908 & -- \\
& $(1.7775,3.4548)$ & $(-0.1247,-0.0569)$ & 0.0138 \\
$\mathrm{Cl}_{10}$ & 4.5914 & -0.9762 & $(0.0036,0.0240)$ \\
& $(1.675,7.5077)$ & $(-1.6694,-0.2830)$ & - \\
$\mathrm{Cl}_{15}$ & 1.0833 & -0.071 & \\
& $(0.4716,1.6949)$ & $(-0.1136,-0.0285)$ & \\
\hline
\end{tabular}

Values in parenthesis indicate confidence intervals $95 \%$ both based in Wald formule (SAS Institute, 2008).

Table 2. Average consumption of $P$. persimilis to different densities of $T$. urticae preys and functional response parameters.

\begin{tabular}{|c|c|c|c|c|c|c|c|c|c|}
\hline \multirow{2}{*}{ No } & \multicolumn{8}{|c|}{$\mathbf{N a} \pm \mathbf{S E}$} & \multirow[b]{2}{*}{$\mathbf{E}$} \\
\hline & Control & $\pm \mathbf{S E}$ & $\mathbf{E}$ & $\mathrm{CL}_{10}$ & $\pm \mathrm{SE}$ & $\mathbf{E}$ & $\mathrm{CL}_{15}$ & $\pm \mathbf{S E}$ & \\
\hline 1 & 1 & \pm 0.000 & 1 & 1 & \pm 0.000 & 1 & 1 & \pm 0.000 & 1 \\
\hline 2 & 2 & \pm 0.000 & 1 & 2 & \pm 0.000 & 1 & 2 & \pm 0.000 & 1 \\
\hline 4 & 4 & \pm 0.000 & 1 & 2.4 & \pm 1.200 & 0.60 & 2 & \pm 0.632 & 0.50 \\
\hline 8 & 8 & \pm 0.000 & 1 & 2.4 & \pm 0.800 & 0.30 & 2 & \pm 0.894 & 0.25 \\
\hline 16 & 9 & \pm 1.000 & 0.56 & 3.8 & \pm 1.326 & 0.24 & 8 & \pm 1.897 & 0.50 \\
\hline 32 & 12.6 & \pm 2.190 & 0.39 & 9 & \pm 2.000 & 0.28 & 9.8 & \pm 0.748 & 0.31 \\
\hline 64 & 21.2 & \pm 2.598 & 0.33 & 15.6 & \pm 1.624 & 0.24 & 10 & \pm 2.280 & 0.16 \\
\hline$\mu$ & $8.257 \mathrm{a}$ & \pm 1.348 & & $5.171 b$ & \pm 0.864 & & $4.971 b$ & \pm 0.809 & \\
\hline a' & 1.078 & $\pm 0.082 *$ & & 0.725 & \pm 0.216 & & 0.798 & \pm 0.232 & \\
\hline $\mathrm{Th}$ & 0.036 & $\pm 0.011^{*}$ & & 0.054 & \pm 0.036 & & 0.068 & \pm 0.019 & \\
\hline $\mathrm{T} / \mathrm{Th}$ & \multicolumn{2}{|c|}{27.78} & & \multicolumn{2}{|c|}{18.52} & \multicolumn{3}{|c|}{14.71} & \\
\hline
\end{tabular}

*Standard error by the method of Jackniffe. Average values followed by a different letter are significantly different from each other. Na: preys consumed. No: preys offered. Th: handling time. a': attack rate. SE: standard deviation. E: Search efficiency. 


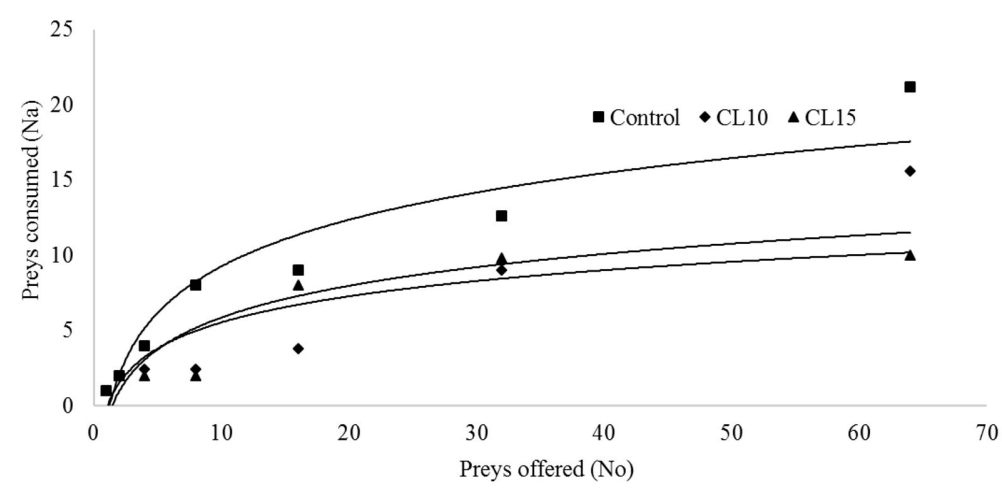

Figure 1. Functional response of adult female of P. persimilis about T. urticae to the exposure of sublethal doses of Abamectin compared to the control with the Holling model.

more time to identify, persecute, consume and digest the prey when it is under the influence of acaricide compared to the control. The search efficiency $(E=N a / N o)$ of the predator decreases when exposed to increased sublethals concentrations of $\mathrm{LC}_{10}$ to $\mathrm{LC}_{15}$. The theoretical maximum number of prey attacked by the predator $P$. persimilis estimated by the asymptote $(T / T h)$ of the functional response curve was 27.77, 18.51 and 14.70 females of T. urticae per day per female for the control, $\mathrm{LC}_{10}$ and $\mathrm{LC}_{15}$ respectively. Theoretical maximum predation decreases when exposed to creased in sublethal concentrations of $\mathrm{LC}_{10}$ and $\mathrm{LC}_{15}$ (Table 2). About it and as a result of predator biological behavior, Reddy (2013) mentions that the decrease in feeding is reflected by the exposure of thin layer residuals Abamectin, when it enters in contact with the mite, it affects the capacity of the neurotransmitters GABA and Glutamate stimulating the flow of chlorine ions into the nerve cells resulting in the loss of the function, these ions that flow inside the channel to an opening result in the loss of the cellular function and interruption of the nervous impulses and consequently, the mites stop their feeding, concluding a negative affect for the predatory mites.

\section{References}

ABBOTT, W.S., 1925. A method of computing the effectiveness of an insecticide. Journal of Economic Entomology, vol. 18, no. 2, pp. 265-267. http://dx.doi.org/10.1093/jee/18.2.265a.

CASTAGNOLI, M., LIGUORI, M., SIMONI, S. and DUSO, C., 2005. Toxicity of some insecticides to Tetranychus urticae, Neoseiulus californicus and Tydeus californicus. BioControl, vol. 50, no. 4, pp. 611-622. http://dx.doi.org/10.1007/s10526-004-8121-7.

CRANHAM, J.E. and HELLE, W., 1985. Pesticide resistance in Tetranychidae. In W. Helle and M.W. Sabelis, eds. Spider mites: their biology, natural enemies, and control. Amsterdam: Elsevier, vol. 1b, pp 405-421.

DESNEUX, N., DECOURTYE, A. and DELPUECH, J.M., 2007. The sublethal effects of pesticides on beneficial arthropods. Annual Review of Entomology, vol. 52, no. 1, pp. 81-106. http://dx.doi. org/10.1146/annurev.ento.52.110405.091440. PMid:16842032.
FINNEY, D.J., 1971. Probit analysis. 3rd ed. Cambridge: The Univiversity Press.

FOURNIER, D., MILLOT, P. and PRALAVORIO, M., 1985. Rearing and mass production of the predatory mite Phytoseiulus persimilis. Entomologia Experimentalis et Applicata, vol. 38, no. 1, pp. 97-100. http://dx.doi.org/10.1111/j.1570-7458.1985.tb03504.x.

HELLE, W. and OVERMEER, W.P.J., 1985. Toxicological test methods. In: W. Helle and M.W. Sabelis, eds. Spider mites: their biology, natural enemies and control. New York: Elsevier, vol. 1a, pp. 391-395.

HERNÁNDEZ, A., GONZÁLEZ, A., CHACÓN, J.C., LANDEROS, J., CERNA, E., FLORES, M. and AGUIRRE, L.A., 2014. Abamectin effect on Chrysoperla carnea (Stephens) functional response. Southwestern Entomologist, vol. 39, no. 2, pp. 261-270. http://dx.doi.org/10.3958/059.039.0204.

HOLLING, C.S., 1959. Some characteristics of simple types of predation and parasitism. Canadian Entomologist, vol. 91, no. 07, pp. 385-398. http://dx.doi.org/10.4039/Ent91385-7.

IBRAHIM, Y.B. and YEE, T.S., 2000. Influence of sublethal exposure to abamectin on the biological performance of Neoseiulus longispinosus (Acari: Phytoseiidae). Journal of Economic Entomology, vol. 93, no. 4, pp. 1085-1089. http://dx.doi. org/10.1603/0022-0493-93.4.1085. PMid:10985016.

JULIANO, S.A. 2001. Nonlinear curve fitting: predation and functional response curves. In: S.M. Scheiner and J. Gurevitch, eds. Design and analysis of ecological experiments. Oxford: Oxford University Press, pp. 178-196.

KIM, S.S. and YOO, S.S., 2002. Comparative toxicity of some acaricides to the predatory mite, Phytoseiulus persimilis and the twospotted spider mite, Tetranychus urticae. BioControl, vol. 47, no. 5, pp. 563-573. http://dx.doi.org/10.1023/A:1016585607728.

LANDEROS, J., GUEVARA, L.P., BADII, M.H., FLORES, A.E. and PAMANES, A., 2004. Effect of different densities of the two spotted spider mite Tetranychus urticae on $\mathrm{CO}_{2}$ assimilation, transpiration, and stomatal behaviour in rose leaves. Experimental \& Applied Acarology, vol. 32, no. 3, pp. 187-198. http://dx.doi. org/10.1023/B:APPA.0000021788.07667.6b. PMid:15139084.

MARTINOU, A.F. and STAVRINIDES, M.C., 2015. Effects of sublethal concentrations of insecticides on the functional response of two mirid generalist predators. PLoS One, vol. 10, no. 12, 
pp. e0144413. http://dx.doi.org/10.1371/journal.pone.0144413. PMid:26641652.

NADIMI, A., KAMALI, K., ARBABI, M. and ABDOLI, F., 2011. Study on persistence tests of miticides abamectin and fenproximate to predatory mite Phytoseiulus persimilis (Acarina: Phytoseiidae). African Journal of Agricultural Research, vol. 6, no. 2, pp. 338-342.

NOUR, E.D.M.E.M. and ABDALLAH, A.A., 2013. Effect of different compounds against Tetranychus urticae Koch and its predatory mite Phytoseiulus persimilis A.H. under laboratory conditions. Journal of Applied Sciences Research, vol. 9, no. 6, pp. 3965-3973.

OLIVEIRA, H., FADINI, M.A., VENZON, M., REZENDE, D., REZENDE, F. and PALLINI, A., 2009. Evaluation of the predatory Phytoseiulus macropilis (Acari: Phytoseiidae) as a biological control agent of the two-spotted spider mite on strawberry plants under greenhouse conditions. Experimental \& Applied Acarology, vol. 47, no. 4, pp. 275-283. http://dx.doi.org/10.1007/s10493008-9217-z. PMid:19016335.

REDDY, P.P., 2013. Recent advances in crop protection: avermectins. New Delhi: Springer India, pp. 13-24 http://dx.doi. org/10.1007/978-81-322-0723-8.

SÁENZ-DE-CABEZÓN, I.F.J., ZALOM, F.G. and THOMSON, P.B., 2007. Residual toxicity of acaricides to Galendromus occidentalis and Phytoseiulus persimilis reproductive potential. Biological Control, vol. 40, no. 2, pp. 153-159. http://dx.doi. org/10.1016/j.biocontrol.2006.10.012.

SAS INSTITUTE, 2008. SAS/STAT user's guide. Cary: SAS Institute Inc.
SEIEDY, M., SABOORI, A., ALLAHYARI, H., TALAEIHASSANLOUI, R. and TORK, M., 2012. Functional response of Phytoseiulus persimilis (Acari: Phytoseiidae) on untreated and Beauveria bassiana treated adults of Tetranychus urticae (Acari: Tetranychidae). Journal of Insect Behavior, vol. 25, no. 6, pp. 543-553. http://dx.doi.org/10.1007/s10905-012-9322-z.

SOHRABI, F., SHISHEHBOR, P., SABER, M. and MOSADDEGH, M.S., 2014. Effects of buprofezin and imidacloprid on the functional response of Eretmocerus mundus Mercet. Plant Protection Science, vol. 50, no. 3, pp. 145-150. http://dx.doi. org/10.17221/64/2012-PPS.

SOLOMON, M.E., 1949. The natural control of animal populations. Journal of Animal Ecology, vol. 18, no. 1, pp. 1-35. http://dx.doi. org/10.2307/1578.

STARK, J.D., BANKS, J.E. and ACHEAMPONG, S., 2004. Estimating susceptibility of biological control agents to pesticides: influence of life history strategies and population structure. Biological Control, vol. 29, no. 3, pp. 392-398. http://dx.doi. org/10.1016/j.biocontrol.2003.07.003.

TALEBI, K., KAVOUSI, A. and SABAHI, Q., 2008. Impacts of pesticides on arthropod biological control agents. Personal Technologies, vol. 2, no. 2, pp. 87-97.

VAN DE VRIE, M., 1985. Greenhouse ornamental. In: W. Helle and M. W. Sabelis, eds. Spider mites: their biology, natural enemies, and control. Amsterdam: Elsevier, vol. 1b, pp. 273-283.

VAN LEEUWEN, T., VONTAS, J., TSAGKARAKOU, A., DERMAUW, W. and TIRRY, L., 2010. Acaricide resistance mechanisms in the two-spotted spider mite Tetranychus urticae and other important Acari: a review. Insect Biochemistry and Molecular Biology, vol. 40, no. 8, pp. 563-572. http://dx.doi. org/10.1016/j.ibmb.2010.05.008. PMid:20685616. 